\title{
Inbreeding effects on exterior traits in Polish konik horses
}

\author{
ANNA WOLC ${ }^{1}$ and KATARZYNA BALIŃSKA ${ }^{2}$
}

${ }^{1}$ Department of Genetics and Animal Breeding, ${ }^{2}$ Department of Horse Breeding, Poznań University of Life Sciences, Poznań, Poland

\section{Abstract}

Conformation traits of 284 Polish konik mares used in breeding until 2005 were analyzed including pedigree information on 477 individuals. Average inbreeding coefficient was in SK Dobrzyniewo 5.9\%, in SK Kobylniki 5.1\%, and 5.6\% in SO Sieraków. No significant effect of inbreeding on conformation traits was observed. Heritability was estimated as: $0.65( \pm 0.13)$ for height at whither, $0.22( \pm 0.14)$ for circuit of chest and $0.65( \pm 0.13)$ for circuit of cannon. Negative phenotypic trend was observed for girth circumference and positive for circuit of cannon. No significant genetic trends were observed for the analyzed traits, which agrees with the assumption of breeding program in genetic reserve flocks.

Keywords: horse, inbreeding rate, Polish konik, heritability, genetic trend

\section{Zusammenfassung}

\section{Zusammenhang zwischen Inzucht und einigen Körperformmerkmalen beim Polnischen Konik}

Es wurden die Körpermaße von 284 Stuten, die bis 2005 für die Zucht genutzt wurden, aus drei für die polnische Konikzucht repräsentativen Zuchtbetrieben erfasst. Für die Abstammungsinformation konnten 477 Tiere einbezogen werden. Die durchschnittlichen Inzuchtkoeffizienten in den drei Gestüten betrugen in SK Dobrzyniewo 5,9\%, in SK Koblylniki $5,1 \%$ und in SO Sierakow 5,6\%. Es konnte kein signifikanter Einfluss des Inzuchtkoeffizienten auf die erfassten Körpermaße festgestellt werden. Die Schätzung der Heritabilität $\left(h^{2}\right)$ ergab für die Widerristhöhe $0,65 \pm 0,13$; den Brustumfang 0,22 $\pm 0,14$ und 0,65 0,13 für den Röhrbeinumfang. Beim Brustumfang zeigte sich ein negativer, beim Röhrbeinumfang ein positiver phänotypischer Trend. Kein genetischer Trend war für die analysierten Körpermaße festzustellen, was das Zuchtprogramm zur Erhaltung dieser Genreserve bestätigt.

Schlüsselwörter: Pferd, Inzucht, Polnischer Konik, Heritabilität, genetischer Trend

\section{Introduction}

Mating of relatives was in the past perceived as a mean to consolidate desired traits. However, it was also observed that inbreeding can lead to increased mortality, decreased fertility and adaptability (FALCONER and MACKAY 1996). High degree of homozygosity breaks the favourable gene combinations which condition correct development of an 

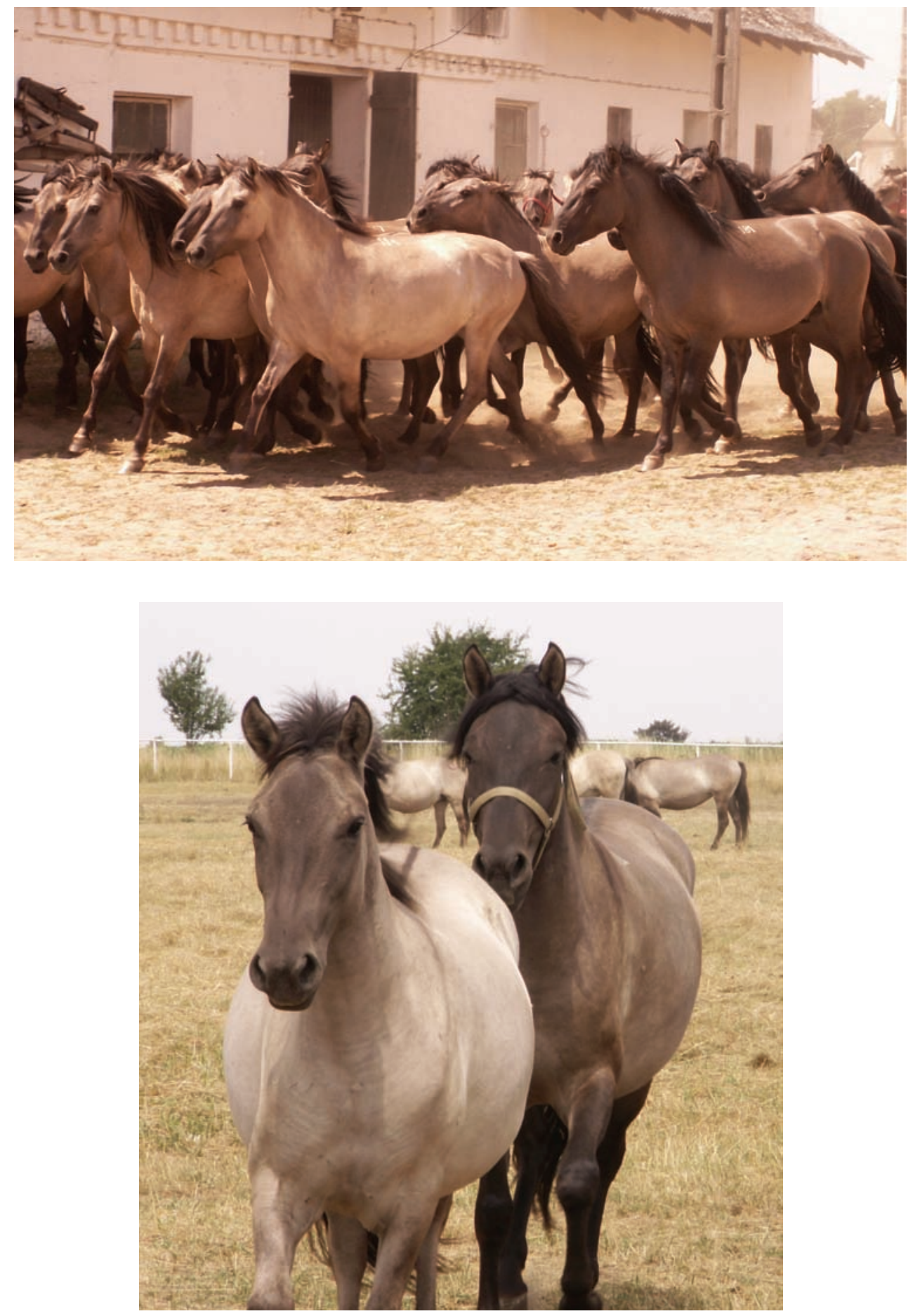

Figure 1

Polish konik

Polnischer Konik 
individual (MATHER 1955). Protection of genetic diversity is the main objective of conservation breeding. The protection of animal genetic resources is supported by the Food and Agriculture Organization (FAO) in the Farm Animal Biodiversity Network (FABISnet) (DUCHEV and GROENEVELD 2006).

Polish konik is a small population of primitive horses in which it is impossible to completely avoid mating of related animals. In 19th century it was possible to meet horses of this breed in forests of Poland, Lithuania and East Prussia. The studbook was set up in 1955. In 1999 breeding program for the population was established and in 2000 Polish konik was included in the program of genetic reserve conservation. The breeding program describes exterior traits necessary to include the horse in the Studbook (type, conformation, body size, coat colour), whereas the conservation program aims at protection and if possible increase in population size of Polish konik which is a valuable resource of biodiversity.

The aims of this study were to: estimate inbreeding level and its effect on basic biometrical measurements in Polish konik mares from three main conservation centres (SK Dobrzyniewo, SK Kobylniki, SO Sieraków); estimate heritability and genetic and phenotypic trends for height at whither, circuit of girth and circuit of cannon.

\section{Material and methods}

The material included pedigree information and biometrical measurements of 284 Polish konik mares used in breeding until 2005 from 3 studs: SK Dobrzyniewo 83 mares (born 1966-2002), SK Kobylniki 138 mares (born 1956-2001), SO Sieraków 63 mares (born 19752002). The studied population can be considered representative for the whole captive bred Polish konik population. Basic information about the population is included in Table 1. In total the pedigree consisted of 477 horses and was traced back to the founders born in 1927. Analysis of genetic structure was conducted using software package CFC (SARGOLZAEl et al. 2006) and included: estimation of individual inbreeding coefficients, founder equivalents, founder genome equivalents and average coancestry within studs. Trends of inbreeding over time were also estimated.

Table 1

Population size, means and standard deviations of biometrical measurements in Polish konik Populationsumfang, Mittelwerte und Standardabweichung der erfassten Körpermaße polnischer Koniks

\begin{tabular}{lccccc}
\hline & $\mathrm{N}$ & mean & SD & min & $\max$ \\
\hline Height at whither & 284 & 135.02 & 2.73 & 128 & 142 \\
Circuit of chest & 284 & 172.69 & 6.81 & 154 & 194 \\
Circuit of cannon & 284 & 17.56 & 0.61 & 15 & 19.5 \\
\hline
\end{tabular}

Genetic parameters were estimated using a single trait animal model:

$$
y_{i j k}=r_{i}+s_{j}+b x_{i j k}+a_{i j k}+e_{i j k}
$$

where $y_{i j k}$ is the vector of observations, $r_{i}$ is the $i$-th year of birth effect, $s_{j}$ is the $j$-th stud effect, $b$ is the linear regression coefficient, $x_{i j k}$ is the inbreeding coefficient of the $i j k$-th horse, $a_{i j k}$ is the additive genetic effect of the $i j k$-th horse and $e_{i j k}$ is the random error for ijk-th observation. 
Variance components were estimated using restricted maximum likelihood algorithm in the DFREML program (MEYER 2000). The relationship between inbreeding level and conformation traits was described by linear regression coefficients including the individual complete generation equivalents as a covariate.

Phenotypic trends were shown by the arithmetic means of conformation traits of mares born within given years. Mares were measured between 30 and 36 months of age at licensing. Genetic trends were estimated as average yearly predicted breeding values.

\section{Results and discussion}

Average inbreeding coefficient of mares in the analyzed studs was equal to $5.4 \%$ including 5.9\% in SK Dobrzyniewo, 5.1\% in SK Kobylniki and 5.6\% in SO Sieraków. Four horses had inbreeding coefficients above $20 \%$. Average number of discrete generation equivalent was 4.2, 4.7, 4.3, for SK Dobrzyniewo, SK Kobylniki and SO Sieraków which shows good pedigree completeness but suggests that lower level of inbreeding in SK Kobylniki can be due to lower pedigree completeness. However, it must be kept in mind that inbreeding level was significantly increasing over the analyzed period (Figure 2) with inbreeding rate (measured by regression coefficient) of 0.11 and reached the level of $8 \%$ already in 1990s. In the most similar population of Dülmener horse the inbreeding rate was $0.91 \%$ per generation (SCHÜLER 2002). Such trends are typical for closed populations where it is impossible to completely avoid mating of relatives. High fluctuations between years result from low numbers of individuals born per year. For the whole population 36 founders were found: 9 stallions and 27 mares. In the SK Dobrzyniewo founder equivalent was equal to 15.4 and founder genome equivalent was 4.2 with average coancestry for the group equal to 0.12., the respective parameters were equal to 14.9, 5.5, 9.1 for SK Kobylniki and 15.4, 4.5, 11 for SO Sieraków. Probabilities of gene origin confirm low values of founder genome equivalents by the fact that 7 founders constituted over $60 \%$ of genes in the analyzed population. Their contributions within the studs are given on Figure 3.

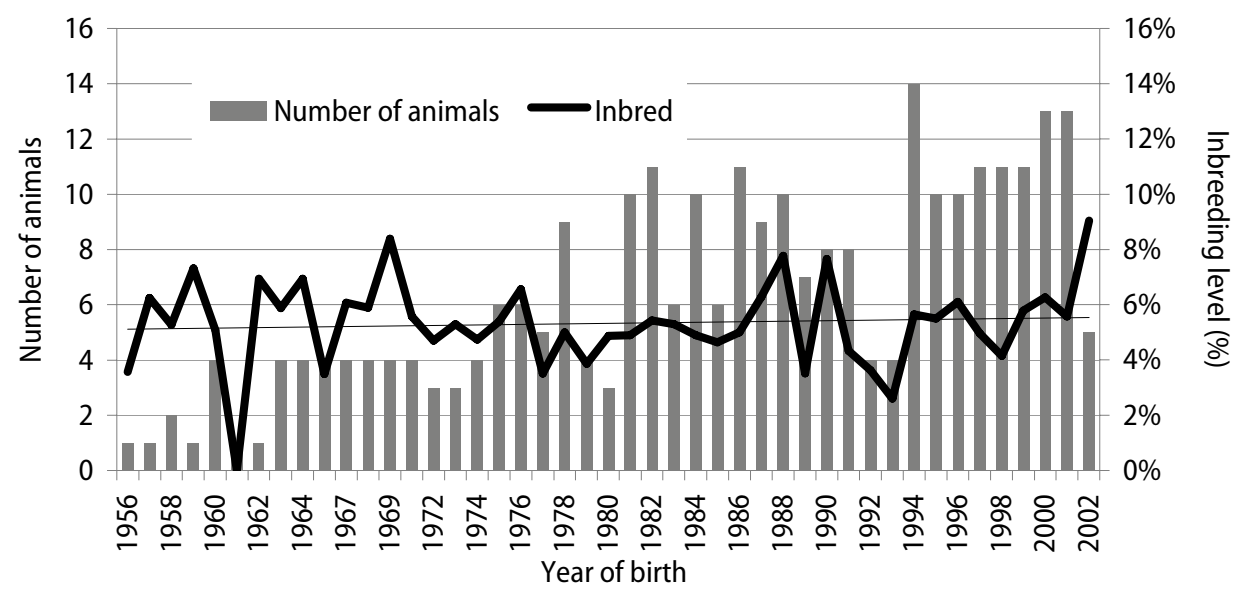

Figure 2

Population size and inbreeding level of Polish konik population

Populationsumfang und Inzuchtrate des Polnischen Konik 


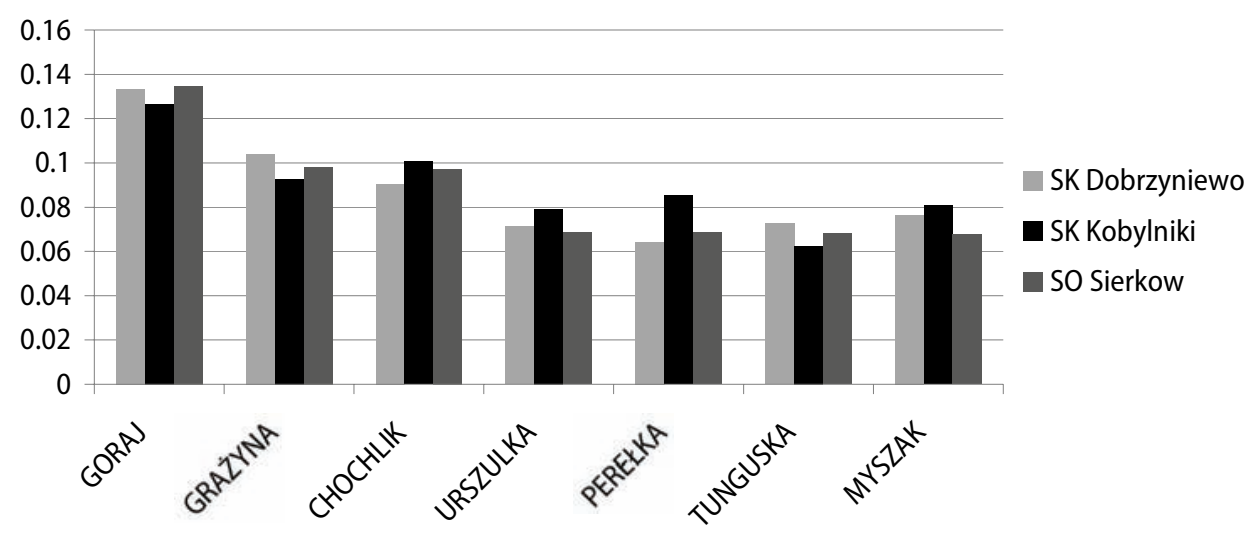

Figure 3

Genetic contribution of the most influential founders to the examined Polish konik studs

Gründerhengste mit dem größten genetischen Einfluss auf die untersuchten Stuten

Other founders were very much underrepresented with some lineages being already extinct or represented by only a single mare. For the comparison in population of Lipizzaner horse 19 individuals account for $50 \%$ of the gene pool (ZECHNER et al. 2002). In the Thoroughbred, Godolphin Arabian is the most important ancestor and accounts for $14 \%$ of the gene pool. Only ten founders are responsible for $50 \%$ of the current Thoroughbred genes (CUNNINGHAM 1991). Complementary information on genetic diversity could be provided by the molecular data (ABERLE and DISTL 2004).

The average high at whither did not undergo substantial changes during the analyzed period whereas some increase for circuit of canon over time was recorded and random fluctuations for the circuit of chest with slight decreasing tendency (Figure 4).

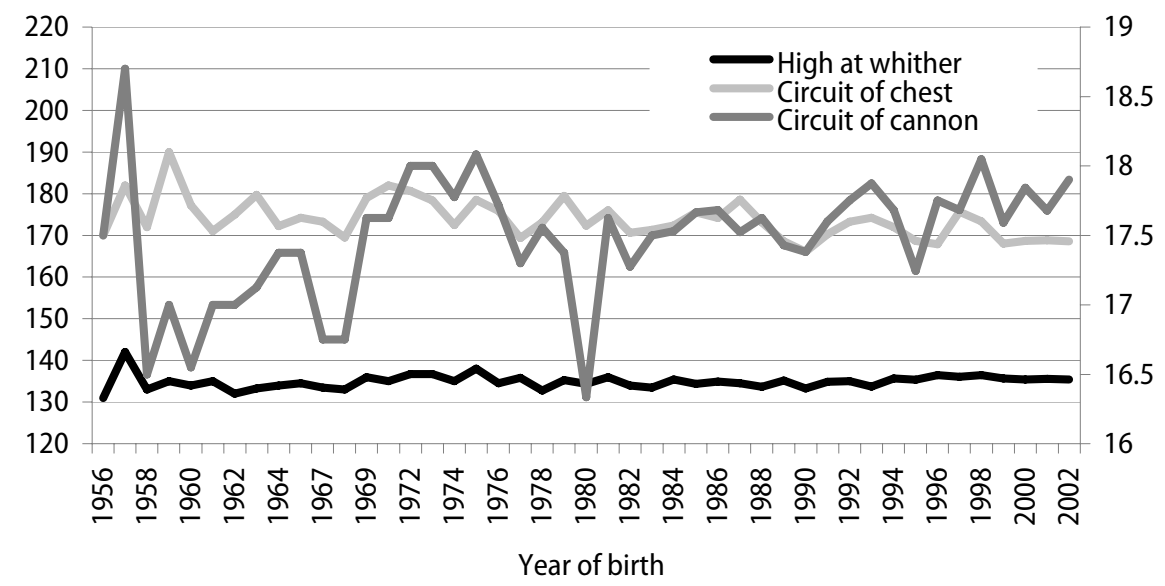

Figure 4

Phenotypic trends of biometrical measurements in Polish konik

Phänotypischer Trend der Körpermaße beim Polnischen Konik 
Inbreeding had no significant effect on the basic biometrical measurements (Table 2), except Sieraków stud where inbreeding was associated with decreased high at withers. The effects of inbreeding on morphological traits were already studied in the Haflinger horse (GANDINI et al. 1992), where significant decrease for height at withers and circumference of chest due to inbreeding was reported. Also in a recent study by GÓMEZ et al. (2009) significant inbreeding depression was found for several biometrical measurements. On the other hand, CURIK et al. (2003) and SIERSZULSKI et al. (2005) found no effect of inbreeding on morphological traits in horses.

Table 2

Linear regression coefficients $(\beta)$ and their standard errors (SE) and significance test of inbreeding effects on biometric measurements of Polish konik

Linearer Regressionskoeffizient, Standardfehler und Signifikanz des Inzuchteinflusses auf Körpermaße

\begin{tabular}{lrrrc}
\hline & $\beta$ & SE & t Value & $\operatorname{Pr}>|t|$ \\
\hline SK Dobrzyniewo & & & & \\
$\quad$ Height at whither & 9.54 & 6.01 & 1.59 & 0.12 \\
Circuit of chest & -0.97 & 14.58 & 0.07 & 0.95 \\
$\quad$ Circuit of cannon & 1.20 & 1.21 & 0.99 & 0.32 \\
SK Kobylniki & & & & \\
$\quad$ Height at whither & -1.16 & 7.40 & 0.16 & 0.88 \\
Circuit of chest & -8.67 & 20.76 & 0.42 & 0.68 \\
$\quad$ Circuit of cannon & 0.23 & 1.66 & 0.14 & 0.89 \\
SO Sieraków & & & & \\
Height at whither & -25.86 & 9.20 & 2.81 & 0.006 \\
Circuit of chest & -24.42 & 19.17 & 1.27 & 0.21 \\
Circuit of cannon & -3.14 & 2.02 & 1.52 & 0.12 \\
\hline
\end{tabular}

In this study the estimates of heritability were equal to $0.65( \pm 0.13)$ for height at whither, $0.22( \pm 0.14)$ for circuit of chest and $0.65( \pm 0.13)$ for circuit of cannon. These estimates should however be treated with caution because of relatively big standard errors resulting from a small population size. There are not many genetic parameters for horses available in the literature and the existing ones mostly focus on noble breeds. For primitive breeds KAPRON et al. (1992) reported heritability for Polish konik of 0.46 for high at whither, and 0.86 for chest circuit. For Hucul horse heritabilities were equal to: height at whither 0.83 , circuit of chest 0.29 and circuit of cannon 0.66 (KAPRON et al. 1993). In Murgese horse the heritability estimates for the three body measurements were found to be 0.24, 0.39 and 0.44 (DIETL et al. 2004, DARIO et al. 2006, HALO et al. 2008). Generally, the estimates are within moderate to high values, however they are usually accompanied by high standard errors because of low numbers of observations. Also low reproductive efficiency (resulting in lack of full-sib groups) and long generation interval in a horse make adequate estimation of genetic parameters difficult (KOMINAKIS 2001).

Over the analyzed periods there were no significant changes in the height at whither, but there was increasing trend for circuit of cannon and slightly decreasing for circuit of chest (Figure 5). There was no significant genetic trend for any trait which agrees with assumption of genetic conservation program. 


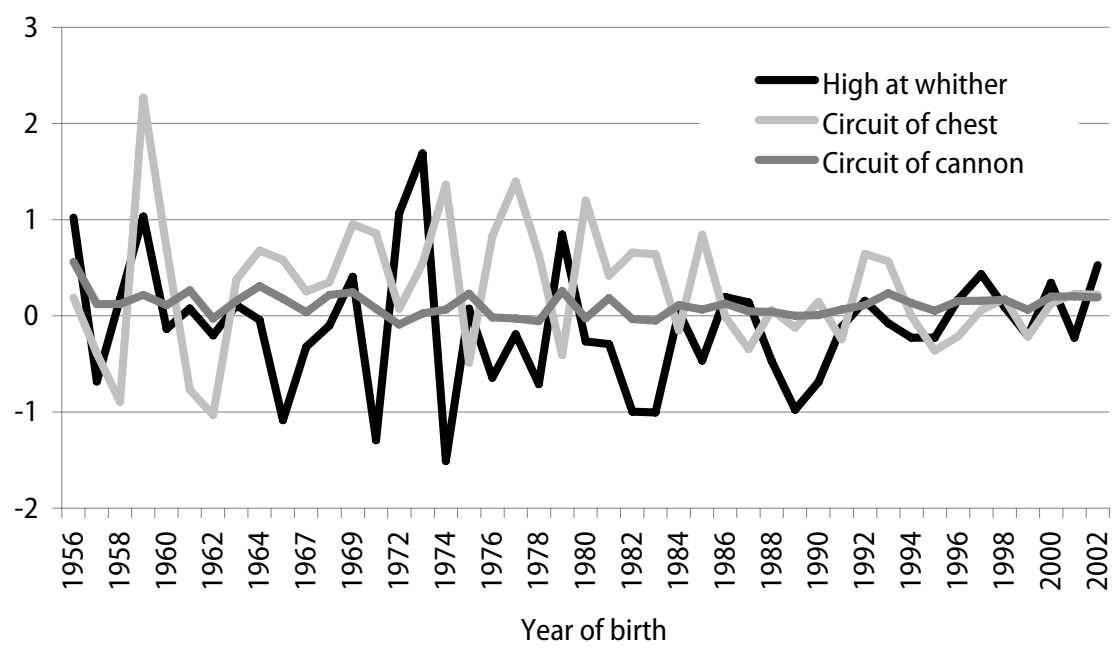

Figure 5

Genetic trends of biometrical measurements in Polish konik

Genetischer Trend der Körpermaße

The present results show that in Polish konik the inbreeding level has been gradually increasing. Very high proportion of genes form very few founders suggest a small gene pool despite not so extremely high inbreeding. In the conservation program which aims at protection of genetic diversity more uniform distribution of founder genotypes would be desired therefore strong attention should be given to preserve genes of underrepresented founders to avoid their extinction.

\section{References}

Aberle KS, Distl O (2004) Domestication of the horse: results based on microsatellite and mitochondrial DNA markers. Arch Tierz 47, 517-35

Curik I, Zechner P, Sölkner J, Achmann R, Bodo I, Dovc P, Kavar T, Marti E, Brem G (2003) Inbreeding, microsatellite heterozygosity, and morphological traits in Lipizzan horses. J Heredity 94,125-32

Cunningham EP (1991) The genetics of Thoroughbred horses. Sci Am 264, 91-8

Dario C, Carnicella D, Dario M, Bufano G (2006) Morphological evolution and heritability estimates for some biometric traits in the Murgese horse breed. Genet Mol Res 5, 309-14

Dietl G, Hoffmann S, Albrecht S (2004) Parameters and trends of mare inspections of Mecklenburger Warmblut Horse. Arch Tierz 47, 107-17 [in German]

Duchev Z, Groeneveld E (2006) Improving the monitoring of animal genetic resources on National and International level. Arch Tierz 49, 532-544

Falconer DS, Mackay TFC (1996) Introduction to Quantitative Genetics, 4th ed Longmans Green, Harlow, Essex, UK

Gandini GC, Bagnato A, Miglior F, and Pagnacco G (1992) Inbreeding in the Italian Haflinger horse. J Anim Breed Genet 109, 433-43

Gómez MD, Valera M, Molina A, Gutiérrez JP, Goyache F (2009) Assessment of inbreeding depression for body measurements in Spanish Purebred (Andalusian) horses. Livest Sci 122, 149-55

Halo M, Mlynek j, Strapák P, Massányi P (2008) Genetic efficiency parameters of Slovak warm-blood horses. Arch Tierz 51, 5-15 
Kaproń M, Bocian K, Słomiany J (1992) Genetic determiantion of conformation tratits in Polish konik. Annales UMCS sec EE X 25, 171-4 [in Polish]

Kaproń M, Pluta M (1993) Genetic determiantion of conformation tratits in hucul horse. Annales UMCS sec EE XI 22, 157-61 [in Polish]

Kominakis AP (2001) Graph analysis of animals' pedigrees. Arch Tierz 44, 521-30

Mather K (1955) The genetical basis of heterosis. Proc Roy Soc Lond Ser B 144, 143-50

Meyer K (2000) DFREML Version 3.0 User Notes

Sargolzaei M, Iwaisaki H, Colleau J (2006) CFC - A software package for pedigree analysis and monitoring genetic diversity

Schüler L (2002) Problems and variants for solutions for breeding in small populations. Arch Tierz $45 \mathrm{SI}$, 20-6 [in German]

Sierszchulski J, Helak M, Wolc A, Szwaczkowski T, Schlote W (2005) Inbreeding rate and its effect on some conformation traits in Arabian mares. Anim Sci Pap Rep 23, 51-9

Zechner P, Sölkner J, Bodo I, Druml T, Baumung R, Achmann R, Marti E, Habe F, Brem G (2002) Analysis of diversity and population structure in the Lipizzan horse breed based on pedigree information. Livest Prod Sci 77, 137-46

Received 15 June 2009, accepted 2 December 2009.

Corresponding author:

\section{ANNA WOLC}

email: awolc@jay.up.poznan.pl

Department of Genetics and Animal Breeding, Poznań University of Life Sciences, Wolynska 33, 60-637

Poznań, Poland 